\title{
W OBRONIE JEDNOŚCI KULTURY BOŚNIACKIEJ. IVAN LOVRENOVIĆ - INTELEKTUALISTA TOTALNY Z SARAJEWA
}

\author{
Dominika Kaniecka \\ Uniwersytet Jagielloński
}

\section{/// Wprowadzenie}

Wyobraźmy sobie człowieka, który mógłby stać się wzorcowym przykładem omawianej przez Pierre’a Bourdieu kategorii ,intelektualisty totalnego”, który - jak Sartre - ucieleśnia figurę „myśliciela-pisarza, powieściopisarza-metafizyka oraz artysty-filozofa, angażującego w toczone w danym momencie walki polityczne cały swój autorytet oraz wszystkie kompetencje, zjednoczone w jego osobie" (Bourdieu 2001: 323), który - mimo galopujących zmian w świecie (być może przez wzgląd na specyfikę lokalnego kontekstu) nie przeistacza się w technokratycznego eksperta. W rolę „tego, który wie" wchodzi świadomie, rozumie zadania, jakie w przestrzeni społecznej czekają na „producentów i dystrybutorów idei” (Bauman 1998: 156). Już na początku swojej drogi zdaje sobie sprawę z ceny tych wyborów i notuje:

Oczekują od ciebie, byś był jasny i szczery. I twoje milczenie jest dla nich nieszczerością. A kiedy nie milczysz, kiedy publikujesz, szczerze i prawdziwie, złoszczą się, zaczynają wytykać cię palcami. Bo nie tego się od ciebie oczekuje. Od ciebie oczekuje się, żebyś 
„szczerze” i „otwarcie” przyznał to, co o tobie myślą (Lovrenović 2013: 247).

Wyobraźmy sobie intelektualistę z Sarajewa, który postanawia: „Być pisarzem! Pisarz to ten, który pisze. Każdego dnia. Wszystko inne to uniki [...]" (tamże: 278), i w postanowieniu tym trwa całe życie, z pełnym rozmysłem, właśnie w Bośni i Hercegowinie działa kompleksowo na polu intelektualnym. Obserwuje i opisuje otaczająca go rzeczywistość. Poszukuje bezcennych fragmentów, z których składa historię kultury swojego kraju. Uważnie i cierpliwie śledzi zmiany w porządku społecznym, przewiduje konsekwencje zawiłej sytuacji politycznej. W krytycznych momentach interweniuje. Jest oddany sprawie, na nieustający brak porządku w bośniackiej rzeczywistości reaguje $\mathrm{z}$ iście havlowskim zaangażowaniem, przez co doświadcza różnych rodzajów wykluczenia.

Tekst ten jest studium przypadku Ivana Lovrenovicia, opisem rezultatów pracy i zaangażowania konkretnego człowieka w obronę jedności własnej kultury, ale także próbą oglądu pewnego typu działalności intelektualnej, uwarunkowanej lokalnymi okolicznościami. Moje rozważania w założeniu mają dowieść totalności Lovrenovicia, mimo względnie niewielkiego zasięgu jego działań. Celem pośrednim jest przybliżenie się do odpowiedzi na pytania o pozycję intelektualisty w tak specyficznym kontekście oraz o mechanizmy regulujące relacje pomiędzy władzą a wiedzą w Bośni i Hercegowinie, której struktura i organizacja jest trudna do zrozumienia nawet dla obywateli tego kraju.

\section{/// Totalność intelektualisty w lokalnym kontekście}

„Władza bez wiedzy jest bezgłowa, wiedza bez władzy jest bezzębna” napisał Zygmunt Bauman, komentując relację, w jakiej intelektualiści pozostają z państwem (Bauman 1998: 157). By zrozumieć realny wymiar działań współczesnego intelektualisty z Sarajewa, należy najpierw zapytać o struktury władzy, której decyzje wyznaczaja granice jego rzeczywistości.

Bośnia i Hercegowina: państwo powstałe po rozpadzie Jugosławii; trzy i pół miliona mieszkańców; terytorium podzielone na dwie główne jednostki administracyjne (Federację Bośni i Hercegowiny, Republikę

\footnotetext{
${ }^{1}$ Fragment pochodzi z dziennika zatytułowanego Tko si ti (1970-2013) (Kim ty jesteś), włączonego do publikacji Nestali u stoljé́u (2013) (Zaginieni w stuleciu). Dziennik nie zawiera szczegółowych dat, ale z porządku opisywanych wydarzeń można wywnioskować, że zapis powstał w latach 70 . Wszystkie cytowane fragmenty przywołuję w przekładzie własnym.
}

\section{/ 126 STANRZECZY 1[16]/2019}


Serbską oraz dodatkowo: dystrykt Brčko²); władza to: trzyosobowe prezydium (złożone z przedstawicieli głównych grup etnicznych: boszniackiej, serbskiej i chorwackiej), dwuizbowy parlament centralny (wybierany z zachowaniem zadanych proporcji związanych z przynależnością narodowa kandydatów), dziesięcioosobowa rada ministrów i premier (z zachowaniem etnicznych proporcji) oraz równolegle: osobni prezydenci, osobne parlamenty, premierzy i ministrowie w obydwu jednostkach administracyjnych (z dodatkowym podziałem Federacji na dziesięć kantonów, z których każdy ma swojego premiera, rząd i władzę ustawodawcza).

Ivan Lovrenović: urodzony w Zagrzebiu (w 1943 r.), uformowany pomiędzy Sarajewem, Zagrzebiem a bośniacką prowincją; dorastał i pierwsza prace podjął w miasteczku Mrkonjić-Grad (dziś na terytorium Republiki Serbskiej); dyplom filologa (jugoslawisty) i etnologa uzyskał w Zagrzebiu; od 1976 roku zawodowo związany z Sarajewem; w czasie wojny zmuszony do opuszczenia mieszkania w okupowanej dzielnicy Grbavica; o oblężonym mieście i wojnie w Bośni pisał na łamach takich czasopism jak: „New York Times”, „Frankfurter Algemeine Zeitung”, „Die Zeit”, „Le Messager Europeen"; lata 1993-1996 spędził na emigracji (Zagrzeb, Berlin), m.in. redagując serię literatury bośniackiej na uchodźctwie (Ex Ponto); do Sarajewa i na Grbavicę wrócił po podpisaniu układu pokojowego w Dayton ${ }^{3}$.

Bauman - powołując się na tezy Michela Foucaulta - ogłosił zmierzch „intelektualistów ogólnych”, wyparcie ich we współczesnym świecie przez profesjonalistów, intelektualistów-ekspertów. Komentując sytuację w Nowym Jorku stwierdził, że „bycie intelektualistą wymaga adresu na campusie" (Bauman 1998: 172, 178). Derrida przypominał o roli uniwersytetów, według niego: ,instytucja to nie marne parę ścian albo jakieś zewnętrzne struktury otaczające, chroniące, gwarantujące lub ograniczające wolność naszej pracy: to jest również i już struktura naszej interpretacji”' (za Hoffman 2018: 163). Czy działalność intelektualną w strukturach (albo poza strukturami) akademii w Nowym Jorku lub Paryżu można porównać do bycia intelektualistą w Sarajewie? Nie sposób odpowiedzieć na to pytanie bez pobieżnego choćby wglądu w organizację życia naukowego na Bałkanach.

\footnotetext{
${ }^{2}$ Według ostatniego spisu powszechnego przeprowadzonego w 2013 roku (opublikowanego dopiero w roku 2016) 70\% mieszkańców Federacji Bośni i Hercegowiny to Boszniacy, 22,44\% stanowia Chorwaci, natomiast 2,5\% - Serbowie. W Republice Serbskiej: $81,51 \%$ to Serbowie, 13,99\% - Boszniacy, Chorwaci stanowią zaledwie 2,4\% mieszkańców. W dystrykcie Brčko: 42,36\% - Boszniacy, 34,58\% - Serbowie, Chorwaci - 20,66\%.

${ }^{3}$ Przytoczone fakty podaję zgodnie z informacjami zamieszczonymi przez autora na jego oficjalnej stronie internetowej: http://ivanlovrenovic.com/biografija (dostęp: 6.09.2019).
} 
Bośnia i Hercegowina: trzy i pół miliona mieszkańców; aż osiem uniwersytetów państwowych ${ }^{4}$, których kadra i programy nie pozostają obojętne na etniczne podziały kraju; ponad dwadzieścia uczelni prywatnych ${ }^{5}$, będących w większości filią bądź kopią uczelni zagranicznych, cztery akademie nauk ${ }^{6}$, skupiające osobno Boszniaków, Serbów i Chorwatów oraz szkoły z trzema różnymi narodowymi programami nauczania (zob. Veličković 2015).

Ivan Lovrenović: niezależny intelektualista z Bośni i Hercegowiny; za jego działaniami na rzecz opisywania i wyjaśniania bośniacko-hercegowińskiej rzeczywistości nie stoi żadna instytucja; w wymiarze światopoglądowym definiuje go jedynie krytyka nacjonalizmu czy nawet jawny wobec niego sprzeciw (Kazaz 2019: 84); za życia doceniony dwudniowym, ale zorganizowanym na prowincji, kongresem (7-8.12.2018 r., Tešanj) i publikacją dotyczącą wyłącznie jego działalności (Ivan Lovrenović. Djelo, 2019); nie jest i nigdy nie był częścią akademii, choć dla wielu jej przedstawicieli, szczególnie zagranicznych, stanowi niekwestionowany autorytet.

Kiedy Teresa Walas omawiała pozycję intelektualisty w okresie transformacji - sięgając za Szackim po kategorię ,intelektualisty moralistycznego”, odpowiadającego kategorii „intelektualisty ogólnego” w rozważaniach Foucaulta - zwróciła uwagę na fakt, ,że każda forma sprawowania władzy wytwarza jakiś rodzaj niesprawiedliwości i cierpienia, każdy porządek partykularny produkuje własny typ niedoskonałości, a każde wcielenie idei zawiera w sobie jakiś błąd” (Walas 2003: 230). W związku z tym intelektualista $z$ założenia powinien być nieuwikłany, ponieważ wskazane wcześniej „niesprawiedliwość, niedoskonałość i nieadekwatność nie pozwalają się sproblematyzować wewnątrz żadnego z tamtych układów i rodzajów działania; widoczne stają się jedynie dla oka usytuowanego na ze-

\footnotetext{
${ }^{4}$ Najstarsze: Uniwersytet w Sarajewie (od 1949 r.), Uniwersytet w Banja Luce (od 1975 r.), Uniwersytet w Tuzli (od 1976 r.) i Uniwersytet „Džemal Bijedić” w Mostarze (od 1977 r.) oraz powstałe w nowej sytuacji geopolitycznej: serbski Uniwersytet Wschodnie Sarajewo (od 1992 r.), chorwacki Uniwersytet w Mostarze (wydzielony w 1993 r. z istniejącej już uczelni); Uniwersytet w Bihaciu (od 1997 r.) i Uniwersytet w Tuzli (od 2000 r.).

${ }^{5}$ Między innymi Międzynarodowy Uniwersytet Burch w Sarajewie; Amerykański Uniwersytet w BiH z oddziałem w Tuzli i Sarajewie; Paneuropejski Uniwersytet Apeiron w Banja Luce; Europejski Uniwersytet Brčko Distrikt w Brčku, Międzynarodowy Uniwersytet Travnik (wszystkie powstały po roku 2000).

${ }^{6}$ Założonaw1966r.ANUBiH-AkademiaNaukiSztukBośniiHercegowinywSarajewieorazpowstałe w nowej sytuacji geopolitycznej (po 1995 r.): BANU - Boszniacka Akademia Nauk i Sztuk w Nowym Pazarze i Sarajewie (od 2011 r.), ANURS - Akademia Nauk i Sztuk Republiki Serbskiej w Banja Luce (od 1996 r.); HAZUBiH - Chorwacka Akademia Nauk i Sztuk Bośni i Hercegowiny w Mostarze (od 2014 r.).
} 
wnątrz" (tamże). Co stanowi o specyfice sieci zależności, w które uwikłany być może intelektualista z Sarajewa?

Bośnia i Hercegowina: trzy i pół miliona mieszkańców; islam, prawosławie i katolicyzm (ale też ślady judaizmu); trzy wiodące - zakorzenione w wyznaniach - narracje i kultury narodowe, podtrzymujące wyrazistość kategorii „my” i „oni”; niestrudzone zastępy polityków, dbających o to, by w debacie publicznej zasada „wszyscy przeciwko wszystkim” nie straciła na aktualności; zdezorientowane społeczeństwo, które - szczególnie w nowym, podaytońskim porządku - potrzebuje „tych, którzy wiedzą”.

Ivan Lovrenović: założyciel i/lub współredaktor czasopism poświęconych kulturze, polityce, nauce i sprawom społecznym (m.in. „Dani”, „Erasmus”, „Tjednik”; po wojnie „Forum Bosnae”); publikował w bezkompromisowym chorwackim polityczno-satyrycznym piśmie „Feral Tribune”; uznaje się go za pioniera bośniackiej etycznie zaangażowanej publicystyki (Kazaz 2019: 85); do 2006 roku aktywnie uczestniczył w różnych formach debaty publicznej (programy telewizyjne, konferencje, panele dyskusyjne) na temat przyszłości wielonarodowej, wielowyznaniowej i multikulturowej Bośni i Hercegowiny; w ostatnich latach skupiony przede wszystkim na działalności pisarskiej i redakcyjnej?

Granice bośniacko-hercegowińskiej rzeczywistości, w której swoją intelektualną misję realizuje Ivan Lovrenović, wyznacza niezwykle zawiły porządek polityczny, specyficzna struktura społeczna i traumatyczna przeszłość. Instytucje naukowe i kulturalne oraz opiniotwórcze media, które mogłyby być oparciem czy obiektem krytyki, oprócz tego, że obciążone są narodową lub partyjną etykieta ${ }^{8}$, niejednokrotnie zwyczajnie niedomagaja.

\section{/// O obronie wspólnej tożsamości kulturowej albo Lovrenovicia tekst o Bośni}

Ivan Lovrenović pisze przez całe życie ${ }^{9}$, pisząc wyjaśnia i walczy o swoje przekonania. Jego działalność jest złożonym, nieustannie rewidowanym

\footnotetext{
Aktualnie pracuje także nad monumentalnym wyborem tekstów bośniackich franciszkanów. W ramach zaplanowanej na dwadzieścia tomów serii Iz Bosne Srebrene - izabrani spisi bosanskih franjevaca od 17. do 20. stoljé́a (Z Bośni Srebrnej- wybrane dokumenty bośniackich franciszkanów od XVII do XX wieku), do 2019 roku opublikowano dziesięć.

${ }^{8}$ Co oczywiście nie oznacza, że w instytucjach tych nie ma niepokornych. W środowisku związanym z Uniwersytetem w Sarajewie wskazać można choćby działalność Envera Kazaza czy Nenada Veličkovicia, niejednokrotnie stojącą w sprzeczności z polityką uczelni.

9 Teksty autorskie publikuje od 1969 roku. Napisał kilka książek prozatorskich, wiele tekstów publicystycznych, kilkanaście tytułów o charakterze eseistyczno-kronikarskim oraz liczne rozprawy na temat bośniackiej kultury i historii.
} 
i uzupełnianym tekstem o Bośni i Hercegowinie, z którego wybrzmiewa odważny postulat uczestnictwa jej mieszkańców w jednej, choć niejednorodnej, kulturze bośniackiej. Takie rozumienie kultury narodowej w kraju Lovrenovicia jest dziś skrajnie niepopularne - nie mieści się w definicjach proponowanych przez ścierające się w przestrzeni publicznej, osobne i naznaczone wątkami nacjonalistycznymi narracje (boszniacką, chorwacką i serbska). Zmiana paradygmatu we wzorcu kulturowym, do jakiej dochodzi po wojnie (1992-1995), wiąże się z ideologizacją i wzmożoną polityczną funkcjonalizacja pola kultury narodowej.

Sięgając po prace Ivana Lovrenovicia, mamy szansę zapoznać się ze stanem sprzed okresu przemian, konsekwencjami nadużyć w obszarze kultury w ostatnich dziesięcioleciach oraz z postulatami na przyszłość. Sarajewski intelektualista w kolejnych tekstach ${ }^{10}$ szczegółowo analizuje proces modelowania wyznaniowej i kulturowej fizjonomii ojczyzny. W rozprawie Unutarnja zemlja. Kratki pregled kulturne povijesti Bosne i Hercegovine (Wewnętrzny kraj. Krótki przegląd historii kulturowej Bośni i Hercegowiny) ${ }^{11}$ jeden z rozdziałów tytułuje „Najbardziej skomplikowany kraj w Europie”. Oceniającego hasła nie zapomina jednak ująć w cudzysłów, jakby próbował odwołać się do zdrowego rozsądku wewnętrznych i zewnętrznych obserwatorów, zaintrygowanych zagadką zamkniętą w tytule. Enver Kazaz zauważa, że budulec kulturowego polilogu, tworzący niegdyś ten ,wewnętrzny kraj”, tradycyjna, nie do końca świadomą swojej multikulturowości Bośnię, wtłoczony został w osobne monologi z mocno zaznaczonymi granicami pomiędzy kulturami narodowymi, które jako samowystarczalne nie wchodza już w żaden dialog (Kazaz 2019: 72).

Lovrenović swoim pisaniem wskazuje drogi do lepszego poznania bośniackiej kultury, wskazuje je sobie (bo pisanie przybliża do zrozumienia) oraz innym, potrzebującym „człowieka, który wie”. Tożsamość kulturowa mieszkańców Bośni i Hercegowiny przybliża, opowiadając o wyimkach z narodowej historii, notując zasłyszane na ulicy dialogi, opisując znaleziska wyszperane w dokumentach rzadko odwiedzanych klasztornych bibliotek, komentując napotkane w podróży pozostałości po bośniackiej przeszłości.

\footnotetext{
${ }^{10}$ M.in. w kulturowo-historycznym eseju Labirint i pamíenje (Labirynt i pamięć) (1989, wyd. 1.), w kolejnych, uzupełnianych wydaniach książki Unutarnja zemlja czy w publikacji przygotowanej wspólnie z M. Jergoviciem, Budućnost nezavršenog rata. 21 teza o Bosni i Hercegovini (Przyszłość niedokończonej wojny. 21 tez o Bośni i Hercegowinie) (2010).

${ }^{11}$ Jedynej publikacji, która spotkała się dużym zainteresowaniem wychodzacym poza kontekst lokalny. Rozprawa ta doczekała się pięciu wydań na terenie byłej Jugosławii (Zagrzeb 1998, 1999, 2004, Sarajewo 2010 i Sarajewo-Zagrzeb 2018) oraz tłumaczenia na język węgierski, czeski, niemiecki i angielski (anglojęzyczne wydanie pt.: Bosnia: A Cultural History, tłum. S. Wild Bićanić i Q. Hoare, NYU Press).
} 
Od swoich poglądów nie odstępuje, omawiając rzeczowo wydarzenia wojenne i nową sytuację geopolityczną.

Pisanie o Bośni i Hercegowinie wymaga konfrontacji z rozpowszechnionym postrzeganiem jej jako głuchej prowincji czy krainy ciemności ${ }^{12}$. Środowiska utrwalające wewnętrzne bośniacko-hercegowińskie antagonizmy winą za propagowanie tego obrazu obarczaja jedynego jugosłowiańskiego noblistę w dziedzinie literatury, Ivo Andricia. Powierzchowne i krzywdzące odczytania jego tekstów sprowadzają się najczęściej do bezrefleksyjnego przywoływania wyrwanego z kontekstu cytatu: „Bośnia to ziemia nienawiści i strachu" (Andrić 1954: 351). Ivan Lovrenović mierzy się z wizją ojczyzny jako „mozaiki wzajemnie wykluczających się elementów" (Karahasan 2014: 182), nie tylko zdejmując z Andricia stygmat wroga kultury narodowej, ale także nawołując do głębszej refleksji nad jego rolą ${ }^{13}$ i zachęcając do poszerzania wiedzy na temat wszystkich składowych wyobrażenia o tym „najbardziej skomplikowanym kraju w Europie”.

Ważnym aspektem starań Ivana Lovrenovicia o zachowanie jedności kultury bośniackiej jest jego troska o dziedzictwo bośniackich franciszkanów. Jednego z braci, fra Ivana Franjo Jukicia ${ }^{14}$, uczynił głównym bohaterem swojej parabiograficznej powieści historycznej Putovanje Ivana Frane Jukića (Podróż Ivana Frana Jukicia), która doczekała się czterech wydań. Można byłoby się pokusić o pewną paralelę pomiędzy idealistyczną postawą i zaangażowaniem dziewiętnastowiecznego zakonnika a zapałem, z jakim współczesny sarajewski intelektualista pracuje na rzecz propagowania wiedzy na temat wspólnego dziedzictwa kulturowego, które powinno łączyć, nie dzielić.

Temat ten obecny jest w poszukiwaniach Lovrenovicia od dawna ${ }^{15}$, ostatnio za sprawą zebrania najważniejszych tekstów powstałych w zakonach franciszkańskich od XVII do XX wieku na terenie Bośni i Hercegowiny $\mathrm{i}$ opublikowania ich $z$ należyta pieczołowitością i adekwatnym apa-

${ }^{12} \mathrm{~W}$ oryg. tamni vilajet. W zerwaniu z negatywnym wyobrażeniem o Bośni pomóc miały inicjatywy podejmowane jeszcze w latach 70. XX wieku w ramach dyskusji nad „bośniackim uniwersalizmem” i bliżej niezdefiniowanym „bośniackim duchem” (więcej na ten temat zob. Jawoszek 2014: 82 i nast.), nie przyniosły one jednak oczekiwanych rezultatów.

${ }_{13}$ Pisarzowi poświęcił osobne studium pt. Ivo Andrić. Paradoks o šutnji (Lovrenović 2008).

${ }^{14}$ Ivan F. Jukić (1818-1857) - propagator bośniackiego patriotyzmu i związanej z nim potrzeby zapoznawania się $z$ własną historią, kulturą i geografią, który w elementarnej wiedzy widział podstawę patriotyzmu.

${ }^{15}$ W licznych publikacjach zawarł skrupulatne notatki dotyczące poszczególnych braci, zakonów, zasobów bibliotek, ale także kompletne analizy problemów związanych z działalnością zakonników w obszarze kultury i edukacji w Bośni i Hercegowinie. Wszystkie zebrane informacje oraz komentarze (własne i cudze) znajdują się na oficjalnej stronie internetowej autora w kategorii Bosna Argentina. Zob. http://ivanlovrenovic.com/clanci/kategorija/bosna-argentina; dostęp: 30.06.2020. 
ratem naukowym. Troska o zapewnienie franciszkanom odpowiedniego miejsca w historii bośniackiej kultury narodowej nie pozostaje bez związku z wielowiekową walką przedstawicieli zakonu o rozwój kultury będącej ponad podziałami konfesyjnymi i narodowymi.

Sarajewski intelektualista głosi niepodzielność kultury bośniackiej mimo świadomości, że od lat 90 . XX wieku trwa jej systematyczny rozkład. Do rozkładu przyczyniaja się: nienaturalny dla jednej wspólnoty podział sił politycznych, przetasowania terytorium i pozorne tylko zakończenie konfliktu (tj. wojny). W takich okolicznościach nie przestaje przypominać o „bośniackim paradygmacie jedności w różnorodności”, czyli możliwej pluralistycznej, ponadwyznaniowej narodowości bośniackiej (Jawoszek 2019: 133), której fundament stanowi przeplatanie się czterech kultur narodowych (włączając żydowska). Odwraca uwagę od politycznej narracji na ten temat, mówiąc o faktycznych, trwalszych niż podkreślane przez polityków, podziałach wynikających ze związku kultury wysokiej z wyznaniem (trzy wielkie religie monoteistyczne nie dość, że przez wieki żądają wyłączności, to jeszcze swoje dziedzictwo zapisują różnymi językami: arabskim, staro-cerkiewno-słowiańskim i hebrajskim). Z przekonaniem głosi, że wspomniane podziały nie wyłączają jednak żadnego mieszkańca Bośni i Hercegowiny z uczestnictwa w tej samej kulturze życia codziennego, będącej wypadkową splatania się wszystkich kultur wyznaniowych, posługiwania się tym samym językiem i identycznymi wzorcami w komunikacji. W ostatnich publikacjach Lovrenović sięga po bardziej precyzyjne terminy, pisze o „dziedzictwie bośniacko-hercegowińskiej tożsamości, która się urzeczywistnia w cywilizacyjnym splocie jednej wspólnej i trzech osobnych tradycji”' (Lovrenović 2015b). Wyraża przy tym jednocześnie zaniepokojenie uśpieniem tej struktury i wiarę w jej trwałość. O szansach na przyszłość pisze następująco:

[...] jej reanimacja i reartykulacja możliwa jest jedynie przy ustanowieniu optymalnych społecznych i politycznych ram, w których wszystkie elementy tej struktury byłyby zrównoważone i mogły bezkonfliktowo dojść do głosu. Dzisiejsza Bośnia i Hercegowina zderza się z tymi pytaniami dramatycznie i niepewnie jak nigdy w swojej historii. Problem jest więc stary, ale odpowiedzi muszą być nowe, ponieważ nowa jest także sytuacja historyczna (tamże). 


\section{/// Bośniacki Chorwat i zaangażowanie}

Zabiegi Lovrenovicia o utrzymanie jedności kultury bośniackiej - czy bośniacko-hercegowińskiej - nie oznaczają oczywiście jego ignorancji wobec istnienia w kraju trzech osobnych konstytutywnych narodów. Przeciwnie, przy wielu okazjach podkreśla on, że wszelkim rozważaniom dotyczącym fundamentalnych kwestii towarzyszyć powinna świadomość dwóch faktów: że niegdysiejsze etniczne i etnokonfesyjne grupy to dziś w politycznym sensie dokończone, kompletne narody oraz że Bośnia przez 500 lat (od 1463 r. do ostatniej wojny) nie posiadała państwowości, co pociaga za sobą określone konsekwencje (Lovrenović 2015a: 26).

Ważnym wątkiem i wykładnią poglądów Ivana Lovrenovicia na temat kształtu kultury bośniackiej jest jego zaangażowanie w debatę poświęcona sytuacji bośniackich Chorwatów (korzystam z terminu utrwalonego przez autora), najmniej licznego spośród trzech konstytutywnych narodów Bośni i Hercegowiny. Konsekwentnie powtarzane apele o prawo do bycia Bośniakiem i Chorwatem jednocześnie, bez ujmy dla którejkolwiek z tych tożsamości i bez konieczności ustalania pomiędzy nimi hierarchii, o prawo do odczuwania dumy z bycia bośniackim Chorwatem, to znak rozpoznawczy sarajewskiego intelektualisty w przestrzeni publicznej.

Kluczowe tezy wyłożył w publikacji pt. Bosanski Hrvati (Bośniaccy Chorwaci), z jakże znaczącym podtytułem: Esej o agoniji jedne evropsko-orijentalne mikrokulture (Esej o agonii pewnej europejsko-orientalnej mikrokultury $)^{16}$. W jednym z wywiadów telewizyjnych przyznał, że książkę pisał $z$ dużym zaangażowaniem emocjonalnym i celowo używał mocnych środków wyrazu. Powstawała ona w czasie ${ }^{17}$, w którym wszyscy prowadzący oficjalną politykę w imieniu albo dla dobra Chorwatów w Bośni i Hercegowinie, w jego przekonaniu, przyczynili się do katastrofy tego „,horwackiego mikrokosmosu". Tekst jest więc jawnym manifestem w obronie własnej mikrotożsamości i ostrzeżeniem przed posługiwaniem się kulturą jako narzędziem w codziennej walce politycznej. Jego celem było zwrócenie uwagi na problem i udało się - publikacja wywołała burzliwe dyskusje ${ }^{18}$.

\footnotetext{
${ }^{16}$ Podobną koncepcję, opisana jednak w dużo bardziej wyważony sposób, zawarł w obszernym haśle „Chorwaci” w specyficznej publikacji, jaka jest Hrvatska enciklopedija Bosne i Hercegovine (Chorwacka Encyklopedia BiH) (red. J. Pehar, t. 2, Hrvatski leksikografski institut Bosne i Hercegovine 2015, s. 409-461).

${ }^{17}$ Książka została opublikowana w 2002 roku, wcześniej jej fragmenty pojawiały się w formie pojedynczych felietonów w tygodniku „Feral Tribune”.

${ }^{18}$ W 2003 roku w Zagrzebiu ukazała się książka Knjiga na knjigu I. Lovrenovića o (bosanskim) Hrvatima (Książka w odpowiedzi na książkę I. Lovrenovicia o [bośniackich] Chorwatach). Jej autor, Jure Krišto, zagrzebski historyk pochodzący z zachodniej Hercegowiny, znany z ataków
} 
Lovrenović w sprawę zaangażował się wcześniej. Na początku lat 90. XX wieku, dokładniej w dniu wyborczego triumfu Franja Tuđmana (jeszcze w ramach socjalistycznej Jugosławii), upublicznił w mediach następująca „diagnoze””, „w stosunku do Bośni i Hercegowiny serbska i chorwacka ideologia narodowa są jak bliźnięta jednojajowe" (Lovrenović 2013: 286). W Zagrzebiu okrzyknięto go zdrajca, ale nie stracił motywacji. Od lat zajęty fenomenem narodu w narodzie, wyrysowywaniem jego teoretycznych ram, pełne zaangażowanie uważał za oczywiste. Brał udział w dyskusji medialnej i bezpośrednich pertraktacjach z politykami. Jeszcze przed wybuchem wojny w Bośni i Hercegowinie uczestniczył w nieudanej próbie osiagnięcia minimalnego choćby porozumienia z prezydentem niezależnej Chorwacji ${ }^{19}$, po czym włączył się w kolejne działania. Wraz z czterema sarajewskimi intelektualistami 6 stycznia 1992 roku napisał list otwarty ${ }^{20}$ do prezydenta będącej wciąż w stanie wojny Chorwacji, Franja Tuđmana. To odważny głos sprzeciwu wobec planów rozczłonkowania Bośni i Hercegowiny $^{21} \mathrm{i}$ apel o poszanowanie interesów zarówno bośniackich Chorwatów, rozsianych po terytorium całego kraju, jak i pozostałych obywateli kraju. W liście tym, po rzeczowym opisaniu dramatycznych okoliczności, paraliżu, w jakim znajdują się bośniackie władze, po wyrażeniu oburzenia analizami i planami Chorwacji wobec sąsiadów, autorzy zamieścili apel o wspieranie „spójności Bośni i Hercegowiny oraz jej międzynarodowego uznania, ponieważ jedynie to leży w długofalowym interesie wszystkich jej narodów, w tym także chorwackiego" (Lovrenović 2002: 248). Jawne gesty niezgody na oficjalną politykę ówczesnej Chorwacji wobec Bośni i Hercegowiny stanowią jeden z najpoważniejszych argumentów w szorstkich relacjach Lovrenovicia z protuđmanowską chorwacką inteligencją Sarajewa, Mostaru i nie tylko. W swojej publicystyce $z$ tamtego okresu reaguje także na plany snute w kraju. Wszystkich, nie tylko Chorwatów z Bośni i Herce-

medialnych na bośniackich franciszkanów, kwestionuje opis specyfiki bośniackich Chorwatów oraz ich chorwackość, cały tekst klasyfikuje pobłażliwie jako ,westchnienia miłośnika Bośni i braci zakonnych" (więcej zob.: Kaniecka 2017: 273-274).

19 Zorganizowana przez Vitomira Lukicia delegacja słyszy w Zagrzebiu o roli bośniacko-hercegowińskich Chorwatów w tworzeniu nowego państwa chorwackiego w związku z brakiem szans na przetrwanie Bośni i Hercegowiny (Lovrenović 2013: 287).

${ }^{20}$ List Otvoreno pismo Franju Tuđmanu, predsjedniku Republike Hrvatske oprócz Lovrenovicia podpisali: M. Jergović, I. Komšić, I. Kordić i M. Stojić. Po raz pierwszy opublikowany został na łamach chorwackiej gazety „Vijesnik” (14.01.1992 r.) wraz z odpowiedzią na niego przygotowana przez Zvonka Leroticia, doradcę ówczesnego prezydenta Chorwacji. 22.01.1992 r. sarajewscy intelektualiści odpowiedzieli tekstem Tko je za, a tko protiv podjele Bosne, na łamach tej samej gazety. List stanowi jeden z aneksów do książki Bosanski Hrvati.

${ }^{21}$ List powstaje jako reakcja na negocjacje prowadzone przez Tuđmana ze S. Miloševiciem i R. Karadžiciem dotyczące przyszłości Bośni i Hercegowiny, o których opinia publiczna dowiaduje się dużo później. 
gowiny, ostrzega przed niebezpieczeństwami, jakie wynikaja z sięgania po narodowo-romantyczne inspiracje, jak choćby „koncepcja Ur-Bośni”, rzekomego prototypu idealnego, który wystarczyłoby tylko przywrócić przy tworzeniu nowych modeli politycznych (Lovrenović 2005: 179).

Niezależnie od reakcji opinii publicznej Ivan Lovrenović trwa przy swoich poglądach. W trosce o przyszłość „,chorwackiego mikrokosmosu" we wspólnym kraju nie stroni nawet od ostrej krytyki kluczowych dla bośniackich Chorwatów środowisk. Najbardziej spektakularne przykłady to jego wystapienia na posiedzeniach Chorwackiej Rady Narodowej Bośni i Hercegowiny ${ }^{22}$. 6 lutego 2007 roku, mówiąc o kulturowej autonomii Chorwatów, wyliczył zaniedbania w najważniejszych instytucjach (włączając samą Radę). Stawiając pytanie o to, dlaczego na czele wszystkich organizacji stoją księża - jasno zasugerował brak szans na ich rozwój i wyjście ze stagnacji (Lovrenović 2015a: 33). W kolejnym referacie zaznaczył, że jego niemile widziana w tych kręgach obecność jest niezbędna, gdyż bez krytyki, a więc bez jego głosu, zmiany w ogóle nie są możliwe (tamże: 33-34). W tym samym wystapieniu podjął palący problem całego kraju, nierozwiązany od podpisania układu pokojowego w Dayton: konieczność wyboru jednej z dróg, na rozstaju których Bośniacy znajdują się stanowczo zbyt długo. Pośród dwóch opcji - skonsolidowane i sprawne państwo trzech narodowości lub stworzenie trzech osobnych państw - stanowczo opowiedział się za tą pierwszą. Jego kolejnym apelom o rozważne decyzje towarzyszyło ubolewanie nad brakiem kompetentnych i szczerze zaangażowanych w sprawę osób (tamże).

\section{/// Historia kultury Bośni i Hercegowiny i prywatna historia Ivana Lovrenovicia}

We wstępie do Liber memorabilium Lovrenović skrupulatnie wylicza: książki, rękopisy, fotografie, dokumenty, szkice esejów, niedokończone teksty, archiwalia i pamiątki porzucone na skutek okoliczności wojennych. Cały księgozbiór bośniackiego intelektualisty został w mieszkaniu, które wraz z rodziną opuścił w 1992 roku. W tym samym roku pożar Biblioteki Narodowej i Uniwersyteckiej w Sarajewie strawił około 80 procent dokumentów ważnych dla historii i dziedzictwa kulturowego Bośni i Hercegowiny. Dwa

\footnotetext{
${ }^{22}$ Hrvatsko narodno vijeće Bosne i Hercegovine (HNVBiH), czyli Chorwacka Rada Narodowa BiH to bezpartyjna pozarządowa organizacja powołana do życia w 1994 roku, kiedy instytucje polityczne nie mogły działać normalnie. Po podpisaniu układu pokojowego w Dayton działa na rzecz wdrażania jego postanowień oraz dbania o interesy narodu chorwackiego w Bośni i Hercegowinie. Na podobnej zasadzie działają organizacje reprezentujące interesy Boszniaków i Serbów w BiH.
} 
miesiące później, w dzielnicy Grbavica, spalono jego prywatną bibliotekę (Lovrenović 2003: 12). Doświadczenie podwójnej straty to część wspólnej traumy przedstawicieli bośniackich środowisk intelektualnych. Lovrenović od najmłodszych lat zainteresowany był zbieraniem zapisków, świadectw czy opowieści. Dziśs, przeglądając jego prace, zauważamy, że w praktykowanym nadal gromadzeniu, dopisywaniu i przedrukowywaniu jest jakaś metoda. Pojedyncze teksty pojawiają się ponownie w kolejnych wyborach i na oficjalnej stronie internetowej autora, nowe wydania książek sa przerabiane i rozbudowywane. Jakby publikacjom towarzyszyć miało dodatkowe zabezpieczenie, żeby odzyskane resztki, odtworzone strzępki, ale też rzeczy nowe na pewno się nie zgubiły.

Ivan Lovrenović swój tekst o Bośni pisze między innymi poprzez odtwarzanie historii własnej, tej pogubionej w spalonych dokumentach, tej nie zawsze rozumianej w świecie własnego dzieciństwa i tej domniemanej, z racji nieznanych losów ojca zaginionego w zawierusze II wojny światowej. Znaczace miejsce w charakterystycznym dla jego narracji wyobrażeniu o wielokulturowej Bośni i Hercegowinie, przefiltrowanej przez osobiste doświadczenia, zajmuje Varcar (dzisiejszy Mrkonjić-Grad). Miasteczko, w którym się wychował i podjął pierwszą pracę, opisuje w eseistyce, we wspomnieniach, w fikcji literackiej, ale także w monografii miasta (Mrkonjić-Grad) i licznych inicjatywach dotyczących jego dziedzictwa ${ }^{23}$. Splatają się w tym miejscu aspekty ważne dla rozumienia koncepcji kultury narodowej, której Lovrenović pozostaje wierny: spotkanie kultury wysokiej i niskiej, wielowyznaniowość i drastyczne zmiany spowodowane przez wojnę.

W zapiskach zatytułowanych Pepeo, uspomene (Popiół, wspomnienia) utrwala obraz miasteczka:

A Varcar był miastem. Tak jak to w Bośni miasta bywają miastami: nie względem liczb, a według właściwości. Najwyraźniej odzwierciedlało się to w języku. Wystarczyło tylko usłyszeć ludzi z okolicznych wiosek jak wymawiają: ide do miasta. Właściciel tych wspomnień [...] pamięta do dziś, z wyraźnym dyskomfortem i tępym niepokojem, kiedy jeszcze w dzieciństwie, w szkole, dzielili się na Chorwatów, Serbów i Muzułmanów, ale to jakoś naturalnie, bez kolizji, że dopiero podział na mieszrzan i wieśniakón nosił w sobie zniewagę i groźbę, zawsze bliską eksplozji (Lovrenović 2013: 27-28).

${ }^{23}$ Jak choćby wystawa dotycząca sté́kón, średniowiecznych kamieni nagrobnych rozsianych po okolicy miasteczka. Treść katalogu z wystawy i materiały fotograficzne znajdują się na stronie internetowej autora (http://ivanlovrenovic.com/clanci/bosna-argentina/stecci-okolice-mrkonjic-grada).

\section{/ 136 STANRZECZY 1[16]/2019}


Varcar jest jak Bośnia i Hercegowina w miniaturze. Od zawsze zamieszkany był głównie przez ludność prawosławna, ale specyfikę lokalnej społeczności określało w pełni nie tyle połączenie kultury ortodoksów ze stanowiącymi mniejszość (ale widocznymi) katolikami i muzułmanami, ile ścieranie się miejskiej i wiejskiej obyczajowości. Zdaniem Lovrenovicia wielowiekowa dominacja ruralnej tradycji pozostawiła w kulturze równie wyraźne ślady jak różnice etnokonfesyjne (Lovrenović 2015b). Antropologiczna ciekawość każe wracać intelektualiście do rodzinnego Mrkonjić-Gradu, tym bardziej, że sytuacja tej miejscowości po wojnie znowu dobrze ilustruje zmiany w pejzażu kulturowym całego kraju. W tekście Lovrenovicia zwiastuja je brutalne ingerencje w tkankę miejską: wysadzenie w powietrze dwóch meczetów i spalenie kościoła.

\section{/// Bośniacko-hercegowiński intelektualista totalny}

Ivan Lovrenović jest intelektualistą mocno osadzonym w lokalnym kontekście, jego walka w obronie jedności kultury bośniackiej oraz kwestii fundamentalnych dla trwania całego kraju realizowana jest od lat poprzez zaangażowanie w bieżące sprawy kulturalne, polityczne i społeczne, ale także poprzez opisywanie i wyjaśnianie dawnego porządku. Ograniczenia, jakie niesie ze sobą bycie intelektualistą na Bałkanach, bycie intelektualista w Bośni i Hercegowinie, mają znamienny wpływ na specyfikę tego zaangażowania.

Zygmunt Bauman w swoich rozważaniach na temat zmiany pozycji intelektualisty we współczesnym świecie słusznie porusza kwestie „konkurencyjności” intelektualnego przesłania na „rynku”, jego udziału w publicznej uwadze (Bauman 1995: 180). Warto się jednak zastanowić, czy myśl ta sprawdza się w odniesieniu do sytuacji intelektualisty z Sarajewa. Bauman przypomina, że - nawet przy nowym układzie sił - nieobecność „wielkich spraw" nie może być wymówką dla wycofania intelektualistów, „bowiem tradycyjnie to sami intelektualiści sprawiali, że sprawy były wielkie, wypisując je na swoich sztandarach i zmuszając prośbą i groźbą opinię publiczną do zwrócenia uwagi, na jaka, jak sądzili, owe sprawy zasługiwały” (tamże). Zanim jednak padnie pytanie o to, czy w podaytońskiej rzeczywistości Bośni i Hercegowiny jeden człowiek może jakimś kwestiom nadać znaczenie proporcjonalne do stopnia swojego zaangażowania, przyjrzyjmy się szerzej pozycji intelektualisty z Sarajewa.

Sam Lovrenović snuje refleksje na ten temat. W swoich przedwojennych jeszcze zapiskach wychodzi od próby porównania polskiego i chor- 
wackiego intelektualisty, od zadumy nad zaoceaniczna (dosłownie i duchowo) sytuacją Witolda Gombrowicza oraz wewnętrzną, warunkowaną regionalnie i cywilizacyjnie - Miroslava Krležy ${ }^{24}$. Przemyślenia zamyka konstatacja:

Kiedy weźmie się pod uwagę całość, Gombrowicz wygrywa. Dlatego (tylko?), że jego problem zyskał znaczenie dla świata; ma światowy zasięg. Krleža jest bardziej tragiczny, jego problem jest dla świata anonimowy. Czy z tego powodu jest mniejszy, mniej istotny? (Lovrenović 2013: 280).

Gombrowicz i Krleža to, podobnie jak Lovrenović, myśliciele totalni, zaangażowani i celnie reagujący na kluczowe dla swoich kultur kwestie. Ich pozycja dziś może być oceniana (jak w przywołanym cytacie) w odniesieniu do ich szczerego oddania sprawie, ale także znaczenia sprawy dla świata. „Wygrana” Gombrowicza można oczywiście podważać; relatywizacja taka jest jednak w tym miejscu zbędna, bo nie o słuszność twierdzenia chodzi, a o gradację ważności i nieważności „sprawy” oraz zabiegających o nią. Przywołane porównanie wprowadza do autorefleksji na temat intelektualnego zaangażowania w kwestie istotne z perspektywy chorwackiego Bośniaka. Samemu sobie Lovrenović zadaje pytanie o możliwe konsekwencje i w wyjaśnieniu wylicza, że „turecka” chorwackość przynosi wstyd, że katolickość kultury jest niemożliwa do wyjaśnienia i wattpliwa bez praktykowania wiary, że ten „folkloryzowany” i „orientalizowany” wariant Europy jest hybrydą egzotyczną w wymiarze lokalnym, a co dopiero szerzej (tamże). Bośniacki intelektualista, we własnej ocenie, przegrywa z Gombrowiczem, Krležą i wieloma innymi, ponieważ uwikłany jest w niejasny i nierzadko nieistotny dla świata kontekst. Jego kultura, uwarunkowana niepraktykowaną czy też, w ostatnich latach, nadmiernie praktykowaną wiarą, jest nie tylko niewidoczna dla świata, ale też niezrozumiała dla wielu jej uczestników. Stawia więc sobie za cel wyjaśnienie fundamentalnych kwestii innym uwikłanym. Zadaje pytania, najpierw bowiem samego siebie musi przekonać, że rozumie i wie, następnie buduje spójną narrację i szuka sposobów na jej rozpowszechnianie, nawet jeśli sprawa jest zupełnie nieistotna dla świata zewnętrznego, to znaczy dla tych, którzy uwikłani nie są.

${ }^{24}$ Miroslav Krleža (1893-1981) to najważniejszy pisarz chorwacki XX wieku, intelektualista o lewicowych poglądach, osobisty przyjaciel Josipa Broza Tity. Znany ze swojej niechęci wobec faszyzmu, nacjonalizmów i krytycznych poglądów na temat chorwackiej tradycji, zbudowanej w jego przekonaniu - na licznych kłamstwach. 
Intelektualista uwikłany w lokalny kontekst często doświadcza różnych form wykluczenia. Lovrenovicia odrzuciły środowiska reprezentujące bośniackich Chorwatów, atakowany był także przez sarajewskich intelektualistów, uznanego pisarza Abdulaha Sidrana czy historyka Srećko M. Džaję i innych. Enver Kazaz przesunięcie Lovrenovicia w bośniacko-hercegowińskiej przestrzeni publicznej od intelektualnej ikony do roli wroga wyjaśnia brakiem gotowości powojennych elit na inicjowane przez niego debaty, brakiem odwagi na konfrontacje z problemem niezakończonej (w wymiarze politycznym) wojny (Kazaz 2019: 90-92). Kazaz wskazuje też konkretny moment świadomego wycofania się tego - jak pisze - „kronikarza upadku bośniacko-hercegowińskiego społeczeństwa” na margines debaty publicznej. Wskazuje kwiecień 2006 roku, kiedy to próby wprowadzenia tzw. pakietu kwietniowego, umacniającego władzę na poziomie centralnym, zakończyły się porażką (tamże: 88).

W 2014 roku, w wywiadzie udzielonym jednej z chorwackich gazet, Ivan Lovrenović precyzyjnie wyjaśnił swoja pozycję. Na pytanie, czy jest chorwackim, bośniacko-hercegowińskim czy bośniackim intelektualistą, odpowiedział następująco:

Wszystkim, co pan wyliczył, jednocześnie. Ale nie statycznie, tylko bardzo dynamicznie. Bośniacko się czuję i reaguję, kiedy z perspektywy nowochorwackiego politycznego szaleństwa neguje się bośniacką tożsamość kulturową i historyczną, tradycję i społeczne praktyki bośniackich franciszkanów itp. Chorwacko - kiedy się w sarajewskich kręgach politycznych i akademickich jednakowo, bośniacko-hercegowińską chorwackość (jak i serbskość, zreszta) ogłasza kategorią importowana, czymś, co nie przynależy do tej historii i tego kraju, więc zgodnie z tym trzeba ją wyrzucić „,z domu”. [...] Bośniacko-hercegowińsko - kiedy ze wszystkich trzech nacjonalistycznych perspektyw narusza się polityczną integralność kraju i z nieznośnym herostratyzmem odnosi do bogatego wspólnego dziedzictwa kulturowego, podczas gdy zagrożone jest jego trwanie. Jako że wszystko, co zostało tu wyliczone, wydarza się w tej samej mierze codziennie, w każdej chwili - tak właśnie się ,widzę” w tych ciasnych ramach zaproponowanych w pytaniu! Najlepiej się czuję i ,widzę" poza nimi, w dobrej samotności! (Jazvić, Lovrenović 2014). 
Doświadczył więc Lovrenović również swoistego samowykluczenia. Miljenko Jergović nazywa go autsajderem z wyboru (Jergović 2019: 100), Ivica Đikić przypomina o korzystnej dla jakości literatury „dobrej samotności” (Đikić 2019: 309). Ja dla porządku rozważań dodam w tym miejscu, że Ivan Lovrenović faktycznie po 2006 roku nad zaangażowaną publicystykę zaczął przedkładać fikcję literacką i jest mniej obecny w mediach, nie zrezygnowal jednak ze swoich poglądów i zabiera głos, kiedy odczuwa ku temu potrzebę. Dzieje się tak na przykład wtedy, gdy przed haski trybunał trafia sześciu chorwackich generałów oskarżonych o zbrodnie w Bośni i Hercegowinie ${ }^{25}$ i gdy jeden z nich, Slobodan Praljak, po ogłoszeniu wyroku skazującego, publicznie odbiera sobie życie na sali sądowej. Kiedy prawicowe środowiska chorwackie bronią swoich „bohaterów”, a pogrzeb Praljaka zamienia się w manifestację patriotyzmu, sarajewski intelektualista zajmuje stanowisko w sprawie i ostrzega przed konsekwencjami politycznej i propagandowej instrumentalizacji tych wydarzeń (Lovrenović 2018). W ostatnich latach Lovrenović był także aktywnym uczestnikiem akcji na rzecz ratowania kluczowych dla zachowania jedności kultury bośniackiej instytucji (m.in. przetrwanie Muzeum Narodowego i powołanie do życia muzeum sztuki współczesneje ${ }^{26}$ ). Nie zamilkł więc, zmienił jedynie intensywność i sposób działania, czasem bowiem świadome przesunięcie się na margines jest jedyną formą skutecznej obrony własnych poglądów.

\section{/// Podsumowanie}

Realia powojennej Bośni i Hercegowiny każdego dnia konfrontują intelektualistów z potrzebą redefiniowania niebezpiecznie nadużywanych w przestrzeni publicznej pojęć. Utrzymujący się od lat impas wynika z braku powszechnie akceptowanej alternatywy dla rozwiązań zapisanych w traktacie pokojowym z Dayton. Bośniacka rzeczywistość w konsekwencji bywa nie do zniesienia. Omawiana przez Baumana konkurencyjność na takim „,ryn-

\footnotetext{
${ }^{25}$ Przed Międzynarodowym Trybunałem Karnym dla byłej Jugosławii w Hadze w 2004 roku stanęło sześciu byłych liderów tzw. Herceg-Bośni (Jadranko Prlić, Slobodan Praljak, Bruno Stojić, Milivoj Petković, Valentin Čorić i Berislav Pušić). Postawione im zarzuty dotyczyły zbrodni dokonanych w latach 1992-1994 na terytorium Zachodniej Hercegowiny i środkowej Bośni. Postępowanie zakończyło się w 2017 roku wyrokiem skazującym oskarżonych na (w sumie) 111 lat więzienia.

${ }^{26}$ Muzeum Narodowe (Zemaljski muzej Bosne i Hercegovine), podobnie zreszta jak Muzeum Literatury i Sztuk Teatralnych, mimo cennych zbiorów i rezultatów wieloletnich badań muzealnych i - co kluczowe - fundamentalnego znaczenia dla kultury Bośni i Hercegowiny, walczy o przetrwanie, ponieważ w rzeczywistości politycznej skoncentrowanej na sprawach narodowych (trzech osobnych: serbskiej, chorwackiej, boszniackiej), miejsca pielęgnujące świadectwa wspólne (albo wspierające i planujące wspólne projekty, jak Muzeum Sztuki Współczesnej Ars Aevi kolekcja bez siedziby) nie znajduja wsparcia u odpowiednich władz.
} 
ku” bez trudu zyskuja politycznie umotywowani „eksperci” od spraw doraźnych, ich przesłanie jednak najczęściej jest krótkoterminowe, podobnie jak dynamika w relacjach władzy i wiedzy we współczesnej Bośni i Hercegowinie. Totalności zaangażowania Lovrenovicia nie ma więc sensu rozpatrywać w odniesieniu do jego skuteczności w czynieniu bronionych kwestii wielkimi, w odniesieniu do konkurencyjności przesłania. Na jej specyfikę składa się w tym przypadku kompleksowość działań skupionych wokół zrozumienia, opisania i systematycznego propagowania idei, w które niezachwianie wierzy, oraz konsekwentna postawa protestu wobec niebezpieczeństwa nacjonalistycznych i totalitarnych kontekstów.

Głos Lovrenovicia mógłby być najdonośniejszym głosem najmniejszego i (w rozpowszechnionej narracji) najbardziej zagrożonego narodu w jego kraju - jest przecież Chorwatem z Bośni i Hercegowiny. Intelektualista wybrał jednak inną perspektywę, niestrudzenie występuje w imieniu interesów wspólnej, bośniackiej kultury, konsekwentnie wskazuje niebezpieczeństwa wynikające z podziału na wyłącznie chorwacki, serbski i boszniacki opis bośniacko-hercegowińskiego świata. Z uporem utrwala obraz Bośni, w której duma z własnej bośniackości nie wyklucza emocjonalnego związku z chorwackością (serbskością czy boszniackościa). Tożsamość kulturową Chorwatów, Serbów i Boszniaków traktuje jako integralną, inkluzywną część socjokulturowego kontekstu Bośni i Hercegowiny. Opisuje, wyjaśnia, komentuje, gdyż w przypadku jego kraju, „z historii, która ma być nauczycielką życia, wciąż można wyciagać wnioski przeczące zdrowemu rozsądkowi" (Mazowiecki 1998: 6). Zadaniem nas, którzy wiemy o jego istnieniu, jest przekazywanie tej wiedzy dalej.

Bibliografia:

/// Andrić I. 1954. List ₹ 1920 roku, tłum. M. Znatowicz-Szczepańska, [w:] tegoż, Pragnienie: opowiadania, Państwowy Instytut Wydawniczy, s. 338-356.

/// Bauman Z. 1998. Nieodwrajemniona mitość: o państwie i intelektualistach, tłum. M. Kwiek, [w:] „Nie pytajcie mnie, kim jestem...”. Michel Foucault drisiaj, red. M. Kwiek, Wydawnictwo Naukowe Instytutu Filozofii UAM, s. $153-181$.

/// Bourdieu P. 2001. Aneks. Intelektualista totalny i ilurja wszechmocy myśli, [w:] tegoż, Reguly sztuki. Geneza i struktura pola literackiego, tłum. A. Zawadzki, Universitas, s. 321-326. 
/// Đikić I. 2019. Dobra samoća. Tri polemike Ivana Lovrenovića o Bosni i Hercegovini, [w:] Ivan Lovrenović. Djelo, red. A. Brka, Centar za kulturu i obrazovanje Tešanj, s. 308-318.

/// Hoffman K. 2018. Profesja. Derrida i uniwersytet, [w:] Widma Derridy, red. A. Bielik-Robson, P. Sadzik, Instytut Badań Literackich PAN, s. 147-165.

/// Jawoszek A. 2014. Boszniacy. Literackie narracje toæ̇samościowe po 1992 roku, Wydawnictwo Nauka i Innnowacje.

/// Jawoszek A. 2019. Naród (Bośnia i Hercegowina), [w:] Leksylkon idei wedrownych na stowianskich Bałkanach XVIII-XXI wiek, red. G. Szwat-Gyłybowa, t. 3, Instytut Slawistyki PAN, Fundacja Slawistyczna, s. 125-132.

/// Jazvić D., Lovrenović I. 2014. Politika Hrvatske prema BiH i danas je talac Franje Tudmana, „Večernji list” 12.04.2014. https://www.vecernji.hr/premium/politika-hrvatske-prema-bih-i-danas-je-talac-franjetudmana-932598; dostęp: 10.12.2019.

/// Jergović M. 2019. Ivan Lourenović, princip autsajdera, [w:] Ivan Lovrenović. Djelo, red. A. Brka, Centar za kulturu i obrazovanje Tešanj, s. 98-118.

/// Kaniecka D. 2017. Chorwaci z Bośni i Hercegowiny czy Chorwaci bośniaccy? Poszukiwania to:̇samości pewnej mikrokultury - rozważania wstępne, „Studia Litteraria Universitatis Iagellonicae Cracoviensis", t. 12, z. 4, s. 263-276.

/// Karahasan Dž. 2014. Doniesienia z krainy ciemności, tłum. M. Waligórski, Pogranicze.

/// Kazaz E. 2019. Ivan Lovrenović - pisac eseističkih uશleta i broničar drustvenog poraza, [w:] Ivan Lovrenović. Djelo, red. A. Brka, Centar za kulturu i obrazovanje Tešanj, s. 9-97.

/// Lovrenović I. 2002. Bosanski Hrvati. Esej o agoniji jedne evropsko-orijentalne mikrokulture, Durieux.

/// Lovrenović I. 2003. Liber memorabilium, Durieux.

/// Lovrenović I. 2006. Iluzija Ur-Bosne, pierwodruk: „Feral Tribune” 12.05.2006, przedruk: „Status”, nr 10/2006, s. 179-180.

/// Lovrenović I. 2008. Ivo Andrić. Paradoks o šntnji, „Motrišta”, nr 41, s. 49-84.

/// Lovrenović I. 2013. Nestali u stoljé́u, Fraktura/Synopsis. 
/// Lovrenović I. 2015a. Isus u Amićima, Synopsis.

/// Lovrenović I. 2015b. Kulturni identitet(i) Bosne i Hercegovine; proširena i preradena verzija s orijentacijskom literaturom (26.04.2015). http://ivanlovrenovic. com/clanci/bosna-argentina/kulturni-identiteti-bosne-i-hercegovine; dostęp: 22.11.2019.

/// Lovrenović I. 2018. Ista nam je kultura poricanja i laganja. http://ivanlovrenovic.com (12.01.2018). http://ivanlovrenovic.com/clanci/intervjui/ivanlovrenovic-ista-nam-je-kultura-poricanja-i-laganja; dostęp: 25.05.2019.

/// Mazowiecki T. 1998. Wstę, [w:] U. Altermatt, Sarajewo przestrzega. Etnonacjonalizm w Europie, Znak.

/// Veličković N. 2015. Trzy sækooly pod jednym dachem. Nacjonalizm w podrecznikach boszniackich, chorwackich i serbskich, tłum. M. Koch, „Poznańskie Studia Slawistyczne", nr 8, s. 283-297.

/// Walas T. 2003. Zrozumié́ swój czas. Kultura polska po komunizmie - rekonesans, Wydawnictwo Literackie.

\section{/// Abstrakt}

Ivan Lovrenović to intelektualista z Sarajewa, pisarz, publicysta, autor esejów i rozpraw na temat bośniackiej kultury i historii. Opis wybranych aspektów działalności Lovrenovicia czyni z tego tekstu studium przypadku. Autorka zadaje pytania o totalność działalności intelektualnej Ivana Lovrenovicia, ale też o pozycję intelektualisty w Bośni i Hercegowinie, ponieważ tekst jest też próbą oglądu pewnego typu działalności intelektualnej uwarunkowanej lokalnymi okolicznościami. Z tekstu wyłania się obraz Lovrenovicia występującego w imieniu interesów wspólnej, bośniackiej kultury, konsekwentnie wskazującego niebezpieczeństwa wynikające z podziału na wyłącznie chorwacki, serbski i boszniacki opis bośniacko-hercegowińskiego świata. Totalność tego intelektualisty rozpatrywana jest przez pryzmat kompleksowości jego działań skupionych wokół zrozumienia, opisania i systematycznego propagowania idei, konsekwentnej postawy protestu, ale także zaangażowania na rzecz obrony zdrowego rozsądku.

Słowa kluczowe:

Ivan Lovrenović, intelektualista totalny, Bośnia i Hercegowina, bośniacki Chorwat, kultura bośniacka 


\section{/// Abstract}

\section{Defending the Unity of Bosnian Culture: Ivan Lovrenović - a Total Intellectual in Sarajevo}

Ivan Lovrenović is an intellectual living in Sarajevo, a writer, publicist, and author of essays and treatises on Bosnian culture and history. This text is a case study describing selected aspects of Lovrenovićs output. The author not only asks questions about the whole of Lovrenovićs intellectual activities but about the position of the intellectual in Bosnia and Herzegovina. She discusses how intellectual activity is conditioned by local circumstances. Lovrenović has advocated a common Bosnian culture, consistently pointing to the danger of dividing descriptions of the Bosnian-Herzegovinan world into solely Croatian, Serbian, and Bosnian parts. Lovrenović is considered a total intellectual on account of the complexity of his activities to understand, describe, and systematically propagate that idea, his consistent attitude of protest, and also his commitment to defending common sense.

Keywords:

Ivan Lovrenović, total intellectual, Bosnia and Herzegovina, Bosnian Croatian, Bosnian culture

/// Dominika Kaniecka - adiunkt w Instytucie Filologii Słowiańskiej Uniwersytetu Jagiellońskiego w Krakowie. Jej zainteresowania naukowe skupiają się wokół zagadnień dotyczących chorwackiej literatury i kultury oraz performatywnego potencjału współczesnego życia społecznego i politycznego. Dotychczasowe badania obejmuja m.in. problematykę tożsamościową (tożsamość narodowa i kulturowa w Chorwacji oraz Bośni i Hercegowinie), ze szczególnym uwzględnieniem dziewiętnastowiecznego dyskursu narodowego i współczesnych do niego odniesień. Opublikowała Opowiedzieć naród. Chorwackość wedtug Augusta Senoi, Kraków 2014. Autorka licznych artykułów publikowanych w monografiach i czasopismach.

ORCID: https://orcid.org/0000-0003-1754-8171

E-mail: dominika.kaniecka@uj.edu.pl 